\title{
Constraints of Recommended Production Technology of Fennel Cultivation by the Farmers in Nagaur District of Rajasthan, India
}

\author{
Sunil Kumar Sharma ${ }^{1 *}$ and N.K. Sharma ${ }^{2}$ \\ ${ }^{1}$ Agriculture Research Station, SKRAU Bikaner, Rajasthan, India \\ ${ }^{2}$ Department of Extension Education SKNAU Jobner, Jaipur, Rajasthan, India \\ *Corresponding author
}

\section{A B S T R A C T}

\section{Keywords}

Fennel growers, Constraints, Knowledge, Large, small and marginal farmers.

\section{Article Info}

\section{Accepted:}

24 February 2017

Available Online:

10 March 2017
Seed spices occupy prominent place in the total basket of spices of the country and play a significant role in our national economy. The group of spices account for about 37 per cent and 18 per cent of the total area and production of spices in the country, respectively. Fennel (Foeniculum vulgare) commonly known as 'Saunf' is an important and highly valued spice grown in India. This crop is widely grown throughout the temperate and subtropical region of the world for its aromatic fruits used in various food preparations such as soups, meat dishes, sauces, pastries, confectionaries, pickles, liquors etc. The fennel seeds are aromatic, stimulants and carminative. Rajasthan is the third largest producer of spices in the country and accounts for $12.48 \%$ of the total production of major spices. The major fennel producing districts of Rajasthan are Nagaur, Sirohi, Jalore, Dausa, Tonk, Sawai Madhopur and contribute above 90 per cent of area and production of fennel crop. Fennel is an important commercial cash crop of arid and semi arid region. There is a wide scope to improve and increase the fennel production and productivity by enhancing the knowledge and adoption of fennel production technology. The present study was conducted in eight villages (four villages from Mertacity tehsil and four villages from Degana tehsil) in Nagaur district of Rajasthan. A sample of 120 fennel growers was selected from these selected villages by using simple random sampling with proportion sample method. The results indicated that 43.33 per cent of the total respondents were in important constraints group, whereas 38.33 per cent in most important and remaining 18.33 per cent respondents were observed in the group of least important constraints in the study area. It was also observed that Poor knowledge about irrigation management and Lack of knowledge about plant protection chemicals (Technical constraints), Supply of inferior quality seed by the agencies and Green color maintaining variety is not available (Input constraints), Lack of knowledge about market intelligence and Incorrect weight measurement by businessman (Marketing constraints), Late sowing reduces the yield and Cloudy weather and rainfall at the time of flowering (Miscellaneous constraints) were perceived as most important constraints by the fennel growers.

\section{Introduction}

India is known the world over as 'The Home of Spices', thus Spices and condiments need no introduction. The climate of the country is ideal for the growth of almost all spices.
Spices are an important group of agricultural goods, which are virtually indispensable in the culinary art. They also play a significant role in our national economy and also in the 
economies of several spice producing, exporting and importing countries. India accounts for about $45 \%$ of the global spice exports. In India, from the point of view of both domestic consumption and export, spices are important commercial crops.

Seed spices occupy prominent place in the total basket of spices of the country and play a significant role in our national economy. The group of spices accounts for about 37 per cent and 18 per cent of the total area and production of spices in the country, respectively. Seed spices are mainly cultivated in the states of Rajasthan, Gujarat, Andhra Pradesh, and Madhya Pradesh. Among these fennel, coriander, cumin, fenugreek, and Ajwain are cultivated on sizeable acreage as compared to other spices. It is the world's largest producer, consumer and exporter of seed spices which are being cultivated widely in the country over different agro climatic zones. Seed spices are not only for home consumption but also for improving economic status of the farmers. In India fennel is cultivated over an area of 1,00,000 ha with the production of $1,43,000$ MT and productivity of $1,430 \mathrm{~kg} / \mathrm{ha}$ (National Horticulture Mission 2011-12).

Fennel (Foeniculum vulgare) commonly known as 'Saunf' is an important dominant and highly valued spice grown in India. This crop is widely grown throught out the temperate and subtropical region of the world for its aromatic fruits used in various food preparations such as soups, meat dishes, sauces, pastries, confectionaries, pickles and liquors etc. The fennel seeds are aromatic, stimulants and carminative.

Fennel oil is used as a flavoring agent in various culinary preparation, confectionary cordials and liquors. The percentage volatile oil in seed varies from 1.5 to 3.5 per cent. It contains 14-22 per cent protein with 12 to 18.5 per cent fat. It is used as a gripe water given to colicky infants. It is used to relieve bronchial spasms because of its antispasmodic properties. It targets the smooth muscles of the respiratory system, stomach muscles and intestines. Herbalists have used it for centuries to induce milk production in nursing mothers.

Rajasthan is the third largest producer of spices in the country and accounts for 12.48 of the total production of major spices. The state produces about $6,96,700$ tones of seed spices from an area of 9,01,628 ha with productivity $4,832 \mathrm{~kg} / \mathrm{ha}$.

The major fennel producing districts of Rajasthan are Nagaur, Sirohi, Jalore, Dausa, Tonk, Sawai Madhopur and occupy above 90 per cent of area and production of fennel crop. The average area, production and productivity of last five years are 13,404 ha, 11,085 tones, $827 \mathrm{~kg} / \mathrm{ha}$ respectively (Vital Agriculture Statistics (2011-12)). So there are possibilities to increase its production by 40 to 50 per cent by adoption of improved technologies.

Fennel is an important commercial cash crop of arid and semi arid region. The production of spices is largely in the hands of small and marginal farmers and the level of productivity of most of the spices in India is below the level as prevailing in other countries. The lower productivity is attributed to lack of knowledge of high yielding varieties, ravages due to pest and diseases, inadequate postharvest technology and poor processing and storage facilities. Keeping this fact in view the present study entitled "The knowledge and adoption of recommended production technology of fennel cultivation by the farmers in nagaur district of Rajasthan" was undertaken.

\section{Materials and Methods}

The present investigation was conducted in purposively selected Nagaur district of 
Rajasthan state highest area and great potential of increasing production and productivity. The researches himself is resident of the area and acquainted with the farmers and their local dialect which facilitated easy rapport building and authentic data collection from the farmers.

The selected consist of twelve tehsils, Out of which two tehsils namely Mertacity and Degana with maximum area under fennel crop production were selected for the study purpose. Separate lists of gram panchayats of the selected tehsils were prepared with the help of concerned 'patwaries' of the Mertacity and Degana tehsils. Mertacity and Degana tehsils comprise of 42 and 34 gram panchayats respectively. Out of which two gram panchayats (Dava and Jaroda kala) from Mertacity tehsil and two gram panchayats (Sanjoo and Chonsli) from Degana tehsil were selected on proportionate random basis. Initially, a complete list of all the major fennel growing villages of the selected tehsils was prepared in consultation with the personnel of revenue department and Agriculture department of the concerned area. From the list so prepared, 4 villages from each Tehsil were identified on the random basis under fennel crop. Thus, in all eight villages were selected for the present investigation. A comprehensive list of all fennel growers was prepared separately for all selected villages of identified tehsils. In preparing the list, the help of revenue personnel and agricultural supervisor of the concerned area was taken for authenticity and counter check of information. Then after the farmers were categorized in to three categories i.e. large, small and marginal farmers, following the procedure laid down above a sample of total 15 respondents i.e. 5 in each category from every selected village was drawn randomly. Thus the study sample for the present investigation was comprised 120 respondents (i.e. 60 from each Tehsil). Keeping in mind the objectives of study, the interview schedule was developed for the collection of data from the selected respondents.

\section{Constraints perceived by respondents in adoption of recommended fennel production technology}

Adoption of technology depends upon various factors which may either accelerate or inhibit the adoption. It is important on the part of extension functionaries to identify such factors so as to make the dissemination of the technology in line with the farmers' perception and need. Therefore the constraints which hinder the adoption of improved fennel production technology were considered in the present study. The constraints under present investigation were considered as major impediments that restrict the farmers to adopt the fennel production technology in their fields. The results have been presented in subsequent tables.

\section{Distribution of respondents on the basis of their level of constraints}

In this section an attempt was made to know the level of constraints perceived by farmers in the adoption of technology The respondents were grouped into (i) least important $(<55.79)$, (ii) important (55.79to 67.46) and (iii) most important (>67.46) group on the basis of calculated mean and S.D. of the obtained constraints' scores by the respondents. The distribution of respondents is given in table 1 .

The data in table 1 depict that 43.33 per cent of the total respondents were in important constraints group, whereas 38.33 per cent in most important and remaining 18.33 per cent respondents were observed in the group of least important constraints in the study area. Analysis of data in table shows that 27.50, 12.50 and 15.00 per cent marginal, small and large farmers perceived least important level 
of constraints respectively. Whereas, 65.00, 32.50 and 32.50 per cent marginal, small and large farmers were observed in the category of important constraints, respectively, further it was found that 7.50, 55.00 and 52.50 per cent marginal, small and large farmers were reported from most important level of constraints group respectively.

From the above matrix, it could be concluded that fennel growers of the study area are experiencing hindrances and bottle-necks in cultivation of crop. The intensity of constraints varies among the farmers of different category.

\section{Category-wise constraints perceived by the respondents}

In the present investigation the constraints were categorized in to 4 suitable categories viz., technical constraints, input constraints, marketing constraints and miscellaneous constraints. The results pertaining to each category are presented in the subsequent tables.

\section{Technical constraints perceived by the respondents}

The data presented in table 2 reveal that "Poor knowledge about irrigation management" was expressed as most important constraints by marginal, small and large farmers with 60.83 , 70.83 and 57.50 MPS, respectively and it was ranked first by marginal and small farmers and fifth by large fennel growers.

Further analysis of table reveals that "Lack of knowledge about plant protection chemicals" was also confronted by marginal, small and large farmers with MPS, 60.83, 59.17 and 65.00 respectively and it was ranked first by the marginal and large and fourth by small farmers.
Likewise, the constraints related to "Lack of knowledge about chemical weed control" was also confronted by marginal, small and large farmers with MPS 60.00, 58.33, and 62.50 respectively and it was ranked second by the marginal and large and fifth by small farmers.

Further analysis of table 2 reveals that "Lack of knowledge about grading and standardization" was also confronted by marginal, small and large farmers with MPS $54.17,65.83$ and 62.50 respectively and it was ranked second by the small and large and fourth by marginal farmers.

The present finding is in conformity with that of Vijay and Malhotra (2001) who reported that major production constraints attributed to low productivity of seed spices are lack of sufficient number of improved varieties to suit different agro climatic situations, lack of proper adoption of improved package of practices and control measures for diseases and pest, non-availability of quality seed of recommended varieties, low and erratic rainfall in certain area, erratic power supply and non-availability of crop insurance cover facilities.

\section{Input constraints perceived by the respondents:}

The data incorporated in table 3 reveal that "Supply of inferior quality seed by the agencies" as constraint was ranked fifth by large farmers, first by small and marginal farmers with 58.33, 69.17 and 62.50 MPS respectively.

The data incorporated in table 3 reveal that "Unavailability of improved seed at time of sowing" was the constraint ranked third by large farmers, second by small farmers and eighth by marginal farmers with 51.67, 63.33 and 60.00 MPS, respectively. 
Table.1 Distribution of the respondents on the basis of level of constraints faced by the respondents in cultivation of fennel

\begin{tabular}{|l|l|l|l|l|l|l|l|l|l|}
\hline \multirow{2}{*}{ S. No. } & \multirow{2}{*}{ Constraints } & Marginal farmers & Small farmers & Large farmers & \multicolumn{2}{l|}{ Total } \\
\cline { 3 - 11 } & & F & $\%$ & F & $\%$ & F & $\%$ & F & $\%$ \\
\hline 1 & $<55.79$ (least imp.) & 11 & 27.50 & 5 & 12.50 & 6 & 15.00 & 22 & 18.33 \\
\hline 2 & 61.63 (important) & 26 & 65.00 & 13 & 32.50 & 13 & 32.50 & 52 & 43.33 \\
\hline 3 & $>67.46$ (most imp.) & 3 & 7.50 & 22 & 55.00 & 21 & 52.50 & 46 & 38.33 \\
\hline Total & 40 & 100.00 & 40 & 100.00 & 40 & 100.00 & 120 & 100.00 \\
\hline
\end{tabular}

Table.2 Technical constraints perceived by the farmers in adoption of recommended fennel production technology

\begin{tabular}{|c|c|c|c|c|c|c|c|c|c|}
\hline \multirow[t]{2}{*}{ S. No } & \multirow{2}{*}{ Technical constraints } & \multicolumn{2}{|c|}{ Marginal farmers } & \multicolumn{2}{|c|}{ Small farmers } & \multicolumn{2}{|c|}{ Large farmers } & \multicolumn{2}{|l|}{ Total } \\
\hline & & MPS & Rank & MPS & Rank & MPS & Rank & MPS & Rank \\
\hline 1. & $\begin{array}{l}\text { Lack of knowledge } \\
\text { about seed treatment }\end{array}$ & 51.67 & $\mathrm{~V}$ & 56.67 & vi & 57.50 & $\mathrm{v}$ & 55.28 & viii \\
\hline 2. & $\begin{array}{l}\text { Lack of knowledge } \\
\text { about grading and } \\
\text { standardization }\end{array}$ & 54.17 & $\mathrm{Iv}$ & 65.83 & ii & 62.50 & ii & 60.83 & iii \\
\hline 3. & $\begin{array}{l}\text { Lack of knowledge } \\
\text { about cultivation of } \\
\text { HYVs }\end{array}$ & 55.00 & Iii & 60.00 & iii & 60.83 & iv & 58.61 & $\mathrm{v}$ \\
\hline 4. & $\begin{array}{l}\text { Lack of knowledge } \\
\text { about recommended } \\
\text { seed rate }\end{array}$ & 54.17 & Iv & 55.83 & vii & 61.67 & iii & 57.22 & vii \\
\hline 5. & $\begin{array}{l}\text { Poor knowledge about } \\
\text { dose of chemical } \\
\text { fertilizer }\end{array}$ & 54.17 & Iv & 58.33 & vii & 53.33 & vi & 55.28 & viii \\
\hline 6. & $\begin{array}{l}\text { Poor knowledge about } \\
\text { irrigation management }\end{array}$ & 60.83 & I & 70.83 & $\mathrm{i}$ & 57.50 & $\mathrm{v}$ & 63.06 & $\mathrm{i}$ \\
\hline 7. & $\begin{array}{l}\text { Lack of knowledge } \\
\text { about plant protection } \\
\text { chemicals }\end{array}$ & 60.83 & I & 59.17 & iv & 65.00 & $\mathrm{i}$ & 61.67 & ii \\
\hline 8. & $\begin{array}{l}\text { Lack of knowledge } \\
\text { about chemical weed } \\
\text { control }\end{array}$ & 60.00 & Ii & 58.33 & $\mathrm{v}$ & 62.50 & ii & 60.28 & iv \\
\hline 9. & $\begin{array}{l}\text { Technical guidance } \\
\text { unavailable at the time } \\
\text { of sowing }\end{array}$ & 54.17 & Iv & 58.33 & $\mathrm{v}$ & 60.83 & iv & 57.78 & vi \\
\hline \multicolumn{2}{|c|}{ Overall } & 56.11 & & 60.37 & & 60.19 & & 58.89 & \\
\hline
\end{tabular}

MPS = Mean per cent score 
Table.3 Input constraints perceived by the farmers in adoption of recommended fennel production technology

\begin{tabular}{|c|c|c|c|c|c|c|c|c|c|}
\hline \multirow{3}{*}{ S. No } & \multirow{3}{*}{ Input constraints } & & & & & & & & \\
\hline & & \multicolumn{2}{|c|}{ Marginal farmers } & \multicolumn{2}{|c|}{ Small farmers } & \multicolumn{2}{|c|}{ Large farmers } & \multicolumn{2}{|l|}{ Total } \\
\hline & & MPS & Rank & MPS & Rank & MPS & Rank & MPS & Rank \\
\hline 1. & $\begin{array}{l}\text { Unavailability of } \\
\text { improved seed at time } \\
\text { of sowing }\end{array}$ & 51.67 & Viii & 63.33 & iv & 60.00 & iii & 58.33 & iv \\
\hline 2. & $\begin{array}{l}\text { Supply of inferior } \\
\text { quality seed by the } \\
\text { agencies }\end{array}$ & 62.50 & I & 69.17 & $\mathrm{i}$ & 58.33 & $\mathrm{v}$ & 63.33 & $\mathrm{i}$ \\
\hline 3. & $\begin{array}{l}\text { Unavailability of } \\
\text { fertilizer at the peak } \\
\text { season }\end{array}$ & 55.00 & $\mathrm{Iv}$ & 51.67 & $\mathrm{xi}$ & 57.50 & vi & 54.72 & vii \\
\hline 4. & $\begin{array}{l}\text { Unavailability of } \\
\text { recommended } \\
\text { chemical for plant } \\
\text { protection measures }\end{array}$ & 58.33 & II & 55.00 & Ix & 59.17 & iv & 57.50 & $\mathrm{v}$ \\
\hline 5. & $\begin{array}{l}\text { Lack of irrigation } \\
\text { facility }\end{array}$ & 56.67 & III & 64.17 & iii & 60.83 & ii & 60.56 & iii \\
\hline 6. & $\begin{array}{l}\text { Uncertainty of good } \\
\text { production }\end{array}$ & 54.17 & $\mathrm{~V}$ & 50.83 & xii & 65.83 & $\mathrm{i}$ & 56.94 & vi \\
\hline 7. & Small land holding & 56.67 & III & 57.50 & vii & 56.67 & vii & 56.94 & vi \\
\hline 8. & $\begin{array}{l}\text { Requires more } \\
\text { organic manure }\end{array}$ & 53.33 & $\mathrm{Vi}$ & 61.67 & vi & 54.17 & $\mathrm{x}$ & 56.39 & vii \\
\hline 9. & $\begin{array}{l}\text { Unavailability of } \\
\text { short duration } \\
\text { varieties }\end{array}$ & 51.67 & VIII & 60.00 & vii & 59.17 & iv & 56.94 & vi \\
\hline 10 & $\begin{array}{l}\text { Green colour } \\
\text { maintaining variety is } \\
\text { not available }\end{array}$ & 56.67 & III & 65.83 & ii & 60.00 & iii & 60.83 & ii \\
\hline 11 & $\begin{array}{l}\text { Seed fertilizer and } \\
\text { chemicals are costly }\end{array}$ & 52.50 & VII & 62.50 & $\mathrm{v}$ & 55.83 & viii & 56.94 & vi \\
\hline 12 & High cost of labour & 52.50 & VII & 53.33 & $\mathrm{x}$ & 55.00 & ix & 53.61 & viii \\
\hline \multicolumn{2}{|c|}{ Overall } & 55.14 & & 59.58 & & 58.54 & & 57.75 & \\
\hline
\end{tabular}


Table.4 Marketing constraints perceived by the farmers in adoption of recommended fennel production technology

\begin{tabular}{|c|c|c|c|c|c|c|c|c|c|}
\hline & & & & & & & & & $=120$ \\
\hline \multirow{2}{*}{ S. No. } & \multirow{2}{*}{$\begin{array}{l}\text { Marketing } \\
\text { constraints }\end{array}$} & \multicolumn{2}{|c|}{ Marginal farmers } & \multicolumn{2}{|c|}{ Small farmers } & \multicolumn{2}{|c|}{ Large farmers } & \multicolumn{2}{|l|}{ Total } \\
\hline & & MPS & Rank & MPS & Rank & MPS & Rank & MPS & Rank \\
\hline 1. & $\begin{array}{l}\text { Lack of storage } \\
\text { facilities }\end{array}$ & 59.17 & III & 65.83 & $\mathrm{i}$ & 61.67 & iii & 62.22 & iii \\
\hline 2. & $\begin{array}{l}\text { Transportation } \\
\text { facilities are very } \\
\text { costly }\end{array}$ & 58.33 & IV & 58.33 & $\mathrm{v}$ & 63.33 & ii & 60.00 & iv \\
\hline 3. & $\begin{array}{lr}\text { Lack } & \text { of } \\
\text { knowledge } & \text { about } \\
\text { market } & \\
\text { intelligence } & \end{array}$ & 67.50 & I & 60.00 & Iii & 61.67 & iii & 63.06 & $\mathrm{i}$ \\
\hline 4. & $\begin{array}{l}\text { Incorrect weight } \\
\text { measurement by } \\
\text { businessman }\end{array}$ & 61.67 & II & 60.83 & $\mathrm{Ii}$ & 65.00 & $\mathrm{i}$ & 62.50 & ii \\
\hline 5. & $\begin{array}{l}\text { Low price of good } \\
\text { quality product in } \\
\text { the market }\end{array}$ & 53.33 & VI & 54.17 & vii & 52.50 & vii & 53.33 & vii \\
\hline 6. & $\begin{array}{l}\text { Unnecessary } \\
\text { deductions in } \\
\text { market at the time } \\
\text { of selling }\end{array}$ & 52.50 & VII & 55.00 & vi & 56.67 & $\mathrm{v}$ & 54.72 & vi \\
\hline 7. & $\begin{array}{l}\text { Minimum support } \\
\text { price is not fixed } \\
\text { in time by the } \\
\text { Govt. }\end{array}$ & 55.00 & $\mathrm{~V}$ & 54.17 & vii & 55.00 & vi & 54.72 & vi \\
\hline 8. & $\begin{array}{l}\text { Very high } \\
\text { fluctuation in price }\end{array}$ & 58.33 & IV & 59.17 & iv & 59.17 & iv & 58.89 & $\mathrm{v}$ \\
\hline Overall & & 58.23 & & 58.44 & & 59.38 & & 58.68 & \\
\hline
\end{tabular}


Table.5 Miscellaneous constraints perceived by the farmers in adoption of recommended fennel production technology

\begin{tabular}{|c|c|c|c|c|c|c|c|c|c|}
\hline \multirow{3}{*}{$\begin{array}{l}\text { S. } \\
\text { No. }\end{array}$} & \multirow{3}{*}{$\begin{array}{l}\text { Miscellaneous } \\
\text { constraints }\end{array}$} & & & & & & & & \\
\hline & & \multicolumn{2}{|c|}{ Marginal farmers } & \multicolumn{2}{|c|}{ Small farmers } & \multicolumn{2}{|c|}{ Large farmers } & \multicolumn{2}{|c|}{ Total } \\
\hline & & MPS & Rank & MPS & Rank & MPS & Rank & MPS & Rank \\
\hline 1. & $\begin{array}{l}\text { Cloudy weather and } \\
\text { rainfall at the time of } \\
\text { flowering and seed for } \\
\text { mation }\end{array}$ & 66.67 & II & 61.67 & iii & 60.00 & ii & 62.78 & ii \\
\hline 2. & $\begin{array}{lr}\text { The early } & \text { showing } \\
\text { fennel crop } & \text { affected } \\
\text { by the } & \text { low } \\
\text { temperature } & \end{array}$ & 60.83 & III & 55.83 & vi & 55.83 & $\mathrm{v}$ & 57.50 & $\mathrm{v}$ \\
\hline 3. & $\begin{array}{l}\text { The harvested fennel } \\
\text { crop affected by the } \\
\text { wind }\end{array}$ & 60.00 & IV & 59.17 & iv & 59.17 & iii & 59.44 & iv \\
\hline 4. & Unable to bear risk & 50.00 & $\mathrm{~V}$ & 56.67 & $\mathrm{v}$ & 52.50 & vi & 53.06 & vi \\
\hline 5. & $\begin{array}{l}\text { Late sowing reduces } \\
\text { the yield }\end{array}$ & 68.33 & $\mathrm{I}$ & 71.67 & $\mathrm{i}$ & 63.33 & $\mathrm{i}$ & 67.78 & $\mathrm{i}$ \\
\hline 6. & $\begin{array}{l}\text { More insect pest } \\
\text { disease attack }\end{array}$ & 60.00 & IV & 65.83 & ii & 57.50 & iv & 61.11 & iii \\
\hline \multicolumn{2}{|c|}{ Overall } & 60.97 & & 61.81 & & 58.06 & & 60.28 & \\
\hline
\end{tabular}

MPS $=$ Mean per cent score

Table.6 Overall constraints perceived by the recommended fennel production technology

\begin{tabular}{|l|l|l|l|l|l|l|l|l|l|}
\hline \multirow{2}{*}{ S. No. } & \multirow{2}{*}{ Constraints } & \multicolumn{2}{|l|}{ Marginal farmers } & Small farmers & \multicolumn{2}{l|}{ Large farmers } & \multicolumn{2}{l|}{ Total } \\
\cline { 3 - 12 } & MPS & Rank & MPS & Rank & MPS & Rank & MPS & Rank \\
\hline 1 & $\begin{array}{l}\text { Technical } \\
\text { constraints }\end{array}$ & 56.11 & III & 60.37 & ii & 60.19 & i & 58.89 & ii \\
\hline 2 & Input constraints & 55.14 & IV & 59.58 & iii & 58.54 & iii & 57.75 & iv \\
\hline 3 & $\begin{array}{l}\text { Marketing } \\
\text { constraints }\end{array}$ & 58.23 & II & 58.44 & iv & 59.38 & ii & 58.68 & iii \\
\hline 4 & $\begin{array}{l}\text { Miscellaneous } \\
\text { constraints }\end{array}$ & 60.97 & I & 61.81 & i & 58.06 & iv & 60.28 & i \\
\hline & Overall & 57.10 & & 59.90 & & 59.07 & & 58.69 & \\
\hline
\end{tabular}

MPS = Mean per cent score 
Table.7 Comparison of constraints perceived by the marginal, small and large farmers in adoption of recommended fennel production technology

\begin{tabular}{|l|l|l|l|l|}
\hline Source of variation & d.f. & SS & MSS & f value \\
\hline Between the categories of farmers & 2 & 183.6500 & 91.8250 & $4.354865^{*}$ \\
\hline Error & 117 & 2467.017 & 21.0856 & \\
\hline Total & 119 & 4052.13 & & \\
\hline
\end{tabular}

* Significant at 5 per cent level.

Mean value table

\begin{tabular}{|l|l|l|l|l|}
\hline $\begin{array}{l}\text { S. } \\
\text { No. }\end{array}$ & Categories of farmers & Mean value & CD & SEM \\
\hline 1. & Marginal farmers & 59.95 & 6.430 & 2.296 \\
2. & Small farmers & 62.90 & & \\
3 & Large farmers & 62.03 & & \\
\hline
\end{tabular}

The data incorporated in table 3 reveal that "Lack of irrigation facility" was the constraint ranked second by large farmers, and third by small and marginal farmers with $60.83,64.17$ and 56.67 MPS, respectively. Further analysis of table 3 reveals that "Unavailability of recommended chemical for plant protection measures" was also perceived as important constraint by marginal, small and large farmers with MPS 58.33, 55.00 and 59.17 respectively and it was ranked second by marginal farmers, ranked ninth by small farmers and fourth by large farmers.

Likewise, the constraints related to "High cost of labor", were also realized as major constraints by the marginal, small, and large respondents and ranked seventh, tenth, and ninth in the order of importance with overall MPS 52.50, 53.33, 55.00, respectively. Further analysis of table 3 reveals that "Small land holding" was also perceived as important constraint by marginal, small and large farmers with MPS 56.67, 57.50 and 56.67, respectively and it was ranked third by marginal, eighth by small, and seventh by large category of respondents.
Likewise, the constraint related to "Require more organic manure" was also realized as major constraint by the respondents and ranked sixth by marginal and small and tenth by large farmers in the priority of constraints with overall MPS as 53.33, 61.67 and 54.17, respectively.

The present finding is in conformity with that of Mutkule et al., (2001) who reported that insecticides and pesticides were very costly, concentration of pesticides not known, fluctuation in prices of chilli, fertilizers were not available in required form in time, costs of fertilizers were very high, lack of disease resistant varieties, non-availability of transport facilities, lack of cold storage and non-availability of sprayers on hire basis were important constraints experienced by the farmers in adoption of chilli cultivation technology.

\section{Marketing constraints perceived by the respondents}

The data presented in table 4 reveal that "Lack of storage facilities" was expressed as 
most important constraint by marginal, small and large farmers with 59.17, 65.83 and 61.67 MPS, respectively and ranked third by marginal and large and first by small farmers.

Further analysis of data in table reveals that "Lack of knowledge about market intelligence" was also perceived as important constraints by marginal, small and large farmers with MPS 67.50, 60.00 and 61.67, respectively and it was ranked first by marginal farmers and third by small and large farmers. Likewise, the constraints related to "Transportation facilities are very costly" were also realized as major constraints by the respondents and ranked fourth by marginal farmers and fifth by small and second by large respondents in the priority of constraints with overall MPS, 58.33, 58.33, and 63.33, respectively.

Further analysis of data in table reveals that "Incorrect weight measurement by businessman" was also perceived as important constraint by marginal, small and large farmers with MPS 61.67, 60.83 and 65.00, respectively and it was ranked second by marginal and small farmers, and first by large farmers. The present finding is in conformity with that of Patel (2005) who reported that high cost of inputs, lack of manpower, irregular supply of electricity, lack of finance, fluctuations in market prices, inadequate irrigation facility, high cost of transport, nonavailability of timely credit and high cost of labor were mentioned as the important constraints by the chilli growers in the Vadodra district of Gujarat.

\section{Miscellaneous constraints perceived by the respondents}

The data incorporated in table 5 reveal that "Late sowing reduces the yield" hinders adoption among marginal, small and large farmers with 68.33, 71.67 and 63.33, MPS respectively. This constraint was ranked first by all the categories of fennel growers. It could be further noted that "Cloudy weather and rainfall at the time of flowering and seed formation" was also perceived as important constraint by marginal, small and large farmers with MPS 66.67, 61.67 and 60.00, respectively and was ranked second by marginal and large farmers and third by small farmers.

Likewise, the constraint related to "More insect pest disease attack" was also realized as major constraint by the respondents and ranked fourth by marginal and large farmers and second by small farmers in the priority of constraints with overall MPS as, 60.00, 65.83 and 57.50, respectively. The present finding is in conformity with that of Nagar (2006) who observed that major constraints perceived by the coriander growers were "unavailability of recommended chemicals for seed treatment", "high cost of chemicals", "high cost of high yielding varieties", "high cost of fertilizers", "unavailability of technical advance, "lack of knowledge about grading and standardization", "unavailability of suitable" equipment's for seed treatment", "timely unavailability of electricity", "lack of suitable equipment's for threshing", "early coriander crop affect by frost", "the harvest coriander crop affected by the wind" and "high losses during storage due to rodents" were the constraints which were perceived with somewhat intensity by the respondents by the study area.

\section{Overall constraints perceived by the recommended fennel production technology}

To get an overview of constraints perceived by the fennel growers, the overall score for each category was pooled and results have been presented in table 6 . 
The data presented in table 6 reveal that among the selected constraints, Miscellaneous and technical constraints were felt up to greatest extent by the fennel growers with MPS 60.28 and 58.89 and were ranked first and second, respectively. These were followed by Input constraints with MPS 57.75 and were ranked fourth, the extent of marketing constraints with MPS 58.68 and third ranked.

Further, when all the four methods were pooled together, the extent of constraints of marginal, small and large farmers was 57.10, 59.90and 59.07MPS respectively. The pooled MPS among the categories of respondents regarding their constraints was found to be 58.69 .

\section{Comparison of constraints perceived by the different categories of fennel growers}

To find out the difference in the constraints perceived by the marginal, small and large farmers in fennel production technology, ' $\mathrm{f}$ ' test was applied. The results are presented in table 7 .

\section{Hypothesis}

$\mathrm{NH}_{03}$ : There is no difference in the constraints perceived by marginal, small and large farmers in adoption of fennel production technology.

$\mathrm{RH}_{03}$ : There is a difference in the constraints perceived by marginal, small and large farmers in adoption of fennel production technology.

The data presented in table 7 show that calculated ' $\mathrm{f}$ ' value (4.354) is more than tabulated ' $\mathrm{f}$ ' value. Thus, the null- hypothesis $\left(\mathrm{NH}_{03}\right)$ is rejected and alternative hypothesis entitled "there is a difference in constraints perceived by marginal, small and large farmers regarding constraints of fennel production technology" was accepted. It means that there existed difference among the three categories of farmers with respect to constraints of fennel production technology.

Constraints perceived by the farmers in the adoption of recommended production technology of fennel

The study revealed that 43.33 per cent of the total respondents were in important constraints group, whereas 38.33 per cent in most important and remaining 18.33 per cent respondents were observed in the group of least important constraints in the study area.

The study indicated that Poor knowledge about irrigation management and Lack of knowledge about plant protection chemicals (Technical constraints), Supply of inferior quality seed by the agencies and Green color maintaining variety is not available (Input constraints), Lack of knowledge about market intelligence and Incorrect weight measurement by businessman (Marketing constraints), Late sowing reduces the yield and Cloudy weather and rainfall at the time of flowering (Miscellaneous constraints) were perceived as most important constraints by the fennel growers.

It was found that there existed difference in the constraints perceived by the marginal, small and large fennel growers in adoption of fennel production technology.

\section{References}

Anonymous. 2010-11. Indian Economy.

Anonymous. 2010-11. Spices Board and CMIE.

Anonymous. 2011-12. Agricultural Statistics, Directorate of Economics and Statistics.

Anonymous. 2011-12. Vital Agriculture Statistics, Deptt. of Agriculture, GOR, Pant Krishi Bhawan, Jaipur. 
Banas Kantha district of Gujarat state". M.Sc. (Ag.) Thesis, G.A.U., Campus-S.K. Nagar.

Choudhary, P.K. and Sharma, N.K. 2008. Constraints in adoption of onion interventions introduced under IVLP in Ajmer region. Rajasthan J. Extension Education, 16: 63-68.

Department of Agriculture and Cooperation, Government of India, New Delhi.

Jaitawat, G.S., Sisodia, S.S. and Bhimawat, B.S. 2007. Constraints in adoption of improved fennel cultivation technology. Indian Res. J. Extension Education, Vol. VII (2\&3): 52-54.

Jangid, N.L. 2001. "Analysis of constraints in the adoption of recommended cultivation practices of chilli by the farmers of panchayat samiti Sambhar lake of jaipur district (Raj)”. M.sc (Ag)
Thesis,R.A.U., campus,jobner.

Lakhera, J.P. and Punjabi, N.K. 1991. "Constraints of fertilizer use". Indian J. Extension Education, 37(3\&4): 114115.

National Horticulture Mission, 2011-12.

Patel, B.A. 1995. "Constraints faced by the farmers in adoption of cumin cultivation technology in

Sharma, L.K. and Gupta, V. 2009. Chilliknowledge and constraints in its scientific cultivation. In Proceeding of National Seminar on Information Technology Application in Agriculture for Livelihood Security of Farmers, organized by Rajasthan society of Extension Educaiton and DEE, Udaipur, from Nov. 10-12: 37.

Vital Agriculture Statistics, 2011-12.

\section{How to cite this article:}

Sunil Kumar Sharma and Sharma, N.K. 2017. Constraints of Recommended Production Technology of Fennel Cultivation by the Farmers in Nagaur District of Rajasthan, India. Int.J.Curr.Microbiol.App.Sci. 6(3): 2326-2337. doi: http://doi.org/10.20546/ijcmas.2017.603.266 